\title{
Amoxicillin Anhydrous
}

National Cancer Institute

\section{Source}

National Cancer Institute. Amoxicillin Anhydrous. NCI Thesaurus. Code C87367.

The anhydrous form of a broad-spectrum, semisynthetic aminopenicillin antibiotic with bactericidal activity. Amoxicillin binds to and inactivates penicillin-binding proteins (PBPs) located on the inner membrane of the bacterial cell wall. Inactivation of PBPs interferes with the cross-linkage of peptidoglycan chains necessary for bacterial cell wall strength and rigidity. This interrupts bacterial cell wall synthesis and results in the weakening of the bacterial cell wall and causes cell lysis. 